\title{
First Records of Freckled Madtom (Noturus nocturnus) in Ohio, USA
}

MATTHEW A. SARVER, Research Associate, Midwest Biodiversity Institute, Hilliard, OH, USA, and CHRIS O. YODER', Research Director, Midwest Biodiversity Institute, Hilliard, OH, USA.

\begin{abstract}
Two new Ohio localities for the Freckled Madtom (Noturus nocturnus Jordan and Gilbert, 1886) were recently discovered. These are the first, and currently only, Freckled Madtom collected in Ohio waters. A single individual was collected in the Scioto River in Scioto County by the Midwest Biodiversity Institute (MBI) and a previously misidentified specimen was collected in the Ohio River at the Hannibal Locks and Dam by the Ohio River Valley Water Sanitation Commission (ORSANCO). The closest historical records are from the Little Sandy River and Big Sandy River drainages in eastern Kentucky. Other Ohio River collections have been made near the border of Kentucky and Indiana. The origins of the recent Ohio specimens are unknown; whether they emanate from other known populations or have been overlooked altogether is unclear.
\end{abstract}

\section{INTRODUCTION}

Madtom species (genus Noturus) are small, obscure catfishes that are generally intolerant of degraded water quality conditions and require specific habitats. Noturus spp. inhabit a range of habitats including high-gradient stretches of streams with riffles comprised of gravel, cobble, and boulder substrates to low-gradient streams with undercut banks, detritus substrates, and woody debris (Burr et al. 2020). Ohio streams and rivers have 5 extant and 1 likely extinct species. The Scioto River drainage has contemporary records for 4 species and all 6 species have been documented; the Ohio River also has historic or current records of 4 species along the Ohio border (Rice and Zimmerman 2019).

Freckled Madtom (Noturus nocturnus) generally inhabits medium-sized streams to large rivers with slight to moderate current, silty sand or gravel substrates, and woody debris (Smith 1979; Burr and Mayden 1982; Robison and Buchanan 2020). Mettee et al. (1996) noted that, in Alabama, Freckled Madtom preferred slow to moderate current over detritus and aquatic vegetation. Eberle (2014) observed Kansas populations in sluggish flows with mud substrates containing detritus. As a cavity nester, Freckled Madtom utilize spaces under rocks and trash in shallow riffles with slow flows for spawning (Burr and Mayden 1982; Robison and Buchanan 2020). Timing for spawning varies, occurring from early May to mid-August in the majority of its range, and through the summer in the southern

\footnotetext{
${ }^{1}$ Address correspondence to Chris O. Yoder, Midwest Biodiversity Institute, 4673 Northwest Parkway, Hilliard, OH 43026, USA. Email: cyoder@mwbinst.com
}

portion of its range (Burr and Mayden 1982; Pflieger 1997; Ross 2001; Robison and Buchanan 2020). It primarily feeds on aquatic macroinvertebrates, preferring larval Ephemeropterans (mayflies), Trichopterans (caddisflies), and Chironomids (midges) (Burr and Mayden 1982; Robison and Buchanan 2020). Feeding occurs primarily at night (Robison and Buchanan 2020).

Freckled Madtom range from Louisiana north to upper Illinois in the Mississippi River drainage, from Illinois to eastern Kentucky in the Ohio River drainage, and in the Mobile River and Brazos River drainages of the Gulf of Mexico (Fig. 1) (Page and Burr 2011). The nearest historic records to Ohio are from Laurel Creek of the Little Sandy River drainage and Levisa Fork of the Big Sandy River drainage, both in eastern Kentucky (Fig. 1) (Clay 1975; Burr 1980). The collection of multiple individuals is rare and sporadic, except in its preferred habitat.

\section{METHODS AND MATERIALS}

Fish collections in the lower Scioto River were conducted by Midwest Biodiversity Institute (MBI) on 5 September 2019 using a pulsed DC electrofishing rig mounted on a Wing ${ }^{\circledR}$ inflatable 4.8-meter (16-foot) raft propelled by a $25 \mathrm{HP}$ outboard motor. The electrode array followed design specifications of Ohio EPA (1989). Pulsed DC electric current was produced by a Honda ${ }^{\circledR}$ GX340 powering a 5,000-watt alternator, and

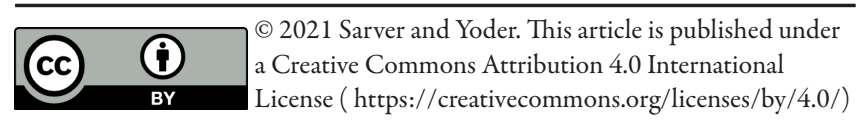




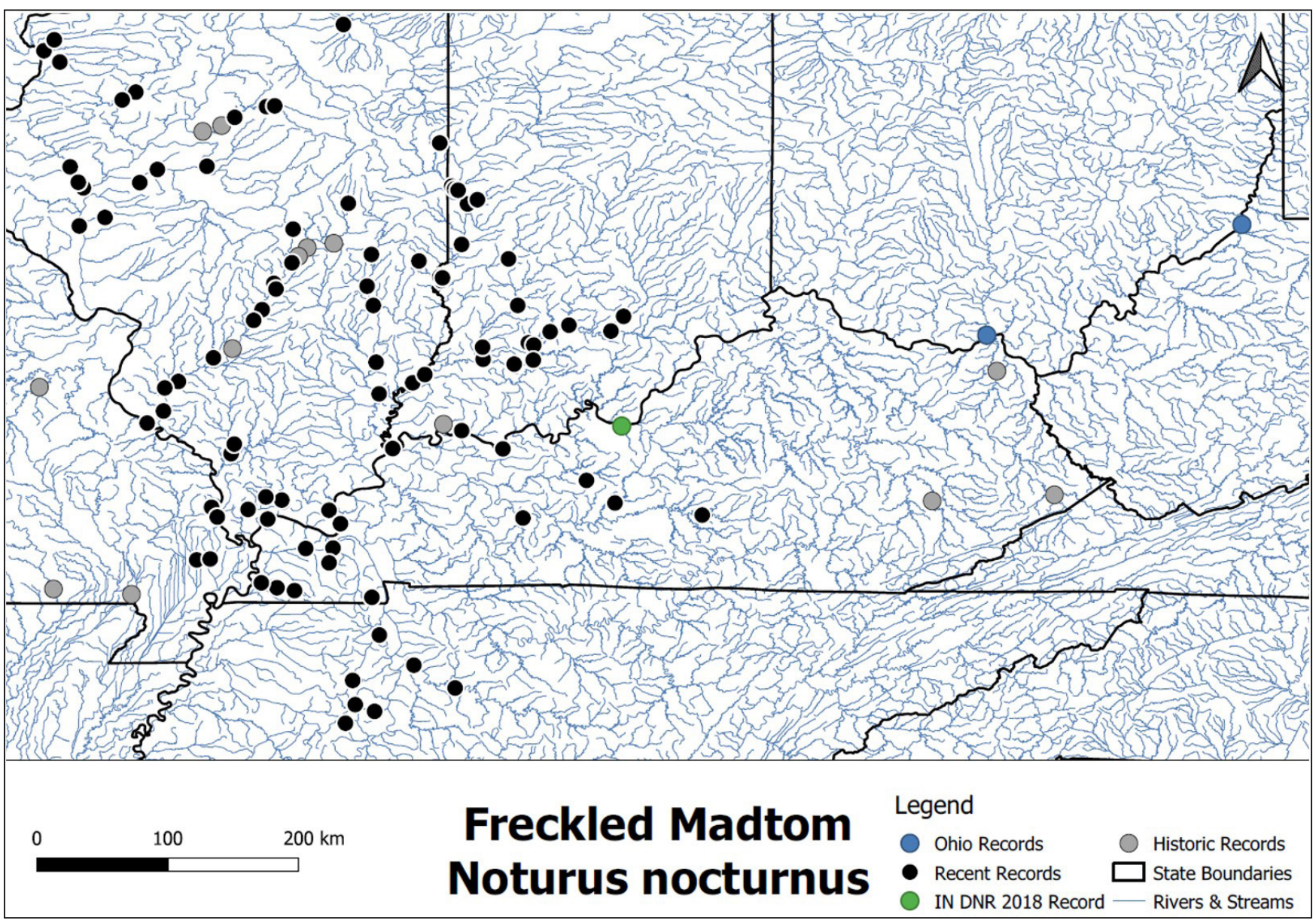

FIGURE 1. Freckled Madtom (Noturus nocturnus) range map primarily focusing on Illinois, Indiana, Kentucky, and the new records in Ohio. Localities are from the Illinois Natural History Survey (INHS), The Ohio State University Museum of Biological Diversity Fish Division (OSUMBD), Brant Fisher of the Indiana Department of Natural Resources (IDNR), Ohio River Valley Water Sanitation Commission (ORSANCO), and the North American Native Fishes Association (NANFA). Historic records are collections made from 1899 to 1960 and recent records are those made post-1960.

controlled by a Smith-Root ${ }^{\circledR} 5.0$ GPP pulsator. Each site included $0.5 \mathrm{~km}(0.31 \mathrm{mi})$ of lineal shoreline and was sampled in an upstream to downstream direction. All habitat types within each site were sampled thoroughly to maximize the collection of all fish species. Stunned fish were collected by a primary netter on the bow of the raft with an assist netter located in the raft behind the livewell. Fish were placed in a 121-liter (32-gallon) aerated livewell using 3.05-meter (10-foot) fiberglass handled dip nets. To reduce stress on the fish and eliminate mortality a 12-volt, 35-watt aerator (powered by a deep-cycle marine battery) was used to oxygenate water in the livewell. All fish were identified to species, counted, weighed, checked for external anomalies, and released back into the water. Fish that could not be accurately identified in the field were retained as voucher specimens and preserved in a $10 \%$ formalin solution. The fish sampling was conducted as a part of a biological and water quality assessment of the lower Scioto River.
The Ohio River Valley Water Sanitation Commission (ORSANCO) sampled Ohio River fish assemblages from lock chambers using 4.9 to 5.5-meter (16 to 18 -foot) johnboats and rotenone at a concentration of 1 part per million ( $\mathrm{ppm}$ ). Fish that floated to the surface were identified, enumerated, weighed, measured, and inspected for anomalies (Thomas et al. 2004). Fish that were not identified in the field were preserved in a $10 \%$ formalin solution and processed in a lab.

Identification of the Freckled Madtom specimens was done by the analysis of morphological and meristic characteristics including pigment, number of pectoral spine barbs, tooth patch morphology, caudal fin ray counts, pelvic fin ray counts, and anal fin ray counts. Dichotomous keys in The Fishes of Illinois (Smith 1979), Inland Fishes of Mississippi (Ross 2001), and The Fishes of Missouri (Pflieger 1997) were used to confirm identification (personal communication on 5 August 2015 from Marc Kibbey to the authors; unreferenced). 


\section{RESULTS}

A single Freckled Madtom was collected in the upper Ohio River on 28 September 2005 by ORSANCO during a lock chamber rotenone survey at the Hannibal Locks and Dam in Monroe County, Ohio. The ORSANCO specimen was originally identified as Stonecat Madtom $\times$ Tadpole Madtom hybrid (Noturus flavus $\times$ Noturus gyrinus) and deposited in the fish collections at the Penn State University (PSUM 10005). The specimen weighed $9 \mathrm{~g}(0.32 \mathrm{oz})$ and had a standard length of $72 \mathrm{~mm}$ (2.83 in). In 2015 it was subsequently identified as a Freckled Madtom by Marc Kibbey, Associate Curator of Fishes, at The Ohio State University Museum of Biological Diversity (OSUMBD) making it the first confirmed record of this species in Ohio. It was collected 309 river km (192 river mi) upstream from the closest known historical localities in the Big Sandy River, Kentucky.

A single Freckled Madtom was collected by MBI on 5 September 2019 in the Scioto River at river $\mathrm{km}$ 2.40 (river mi 1.50), upstream from US-52, just west of Portsmouth, Ohio. Not as far removed from the known historic range as the Ohio River specimen collected in 2005, this is the first Freckled Madtom collected within the interior of the state of Ohio. It was collected in a sandy run that had moderate flow and large woody debris. It weighed $20 \mathrm{~g}(0.7$ oz) and had a standard length of $95 \mathrm{~mm}$ (3.74 in). The preserved specimen was identified by Marc Kibbey of OSUMBD and Brian Zimmerman of The Ohio State University Stream \& River Ecology (STRIVE) Lab in 2020. This specimen was deposited at The Ohio State University Museum of Biological Diversity (OSUM 120620).

Identification of the Freckled Madtom (Fig. $2 \mathrm{~A}$ and $2 \mathrm{~B}$ ) was done through the comparison of meristic, morphological, and pigmentation characteristics, plus the use of dichotomous keys in the previously cited ichthyological texts. The Freckled Madtom has similarities closest to 2 Ohio madtom species, the Stonecat Madtom (Noturus flavus) (Fig. 2C) and Tadpole Madtom (Noturus gyrinus) (Fig. 2D), plus the hybrid Noturus gyrinus $\times$ Noturus miurus described by Trautman (Fig. 2E) (Table). Freckled Madtom differs from Tadpole Madtom by the upper jaw of the Freckled Madtom extending beyond the lower jaw and by the dorsal, anal, and caudal fins having black margins. Freckled Madtom also has freckled pigmentation on the lower lip and chin, and a tooth patch on the upper jaw that lacks backward extensions that distinguish it from the Stonecat Madtom. None of these species have barbs on the pectoral spines (Fig. 3). Specifically, the Freckled Madtom specimens collected in Ohio had (1) the discrete speckles on the lower sides and on the otherwise light belly compared to the Tadpole Madtom with a more uniformly pigmented belly and (2) the lack of a backward extension of the tooth patch of the Stonecat Madtom (personal communication on 5 August 2015 from Marc Kibbey to the authors; unreferenced).

\section{DISCUSSION}

Milton Trautman and Carl Hubbs misidentified a hybrid madtom as a Freckled Madtom that was collected in Lake Erie on 27 June 1929 by Edward Wickliff (Trautman 1948). Trautman and Hubbs, not being confident of their original identification, later examined the specimen; Trautman determined it was a hybrid between the Brindled Madtom and Tadpole Madtom based on morphological characteristics (OSUM 12862) (Trautman 1948). As with the 1929 hybrid specimen, each of the 2 recent Ohio collections of Freckled Madtom were initially misidentified.

The Freckled Madtom specimen collected in the Scioto River was initially identified by the lead author as a Tadpole Madtom, similar to how the Ohio River specimen was misidentified as a hybrid between Stonecat Madtom $\times$ Tadpole Madtom by ORSANCO. The common thread with each misidentification is Tadpole Madtom, which raised the possibility of prior misidentifications of Tadpole Madtom (or its hybrids) in the lower reaches of moderate to large Ohio River tributaries. This prompted the authors to reexamine available specimens, identified as Tadpole Madtom from the lower Scioto River drainage, in the OSUMBD collections; however, all were confirmed as Tadpole Madtom. While there are few records of Tadpole Madtom from the lower Scioto River mainstem proper, none had voucher specimens available in the OSUMBD fish collections.

The nearest historical locality for the Freckled Madtom to the Ohio River specimen, collected in 2005, is in the Big Sandy River drainage in Kentucky. This large river tributary to the Ohio River is 309 river $\mathrm{km}$ (192 river mi) downstream from the Hannibal Locks and Dam near Hannibal, 

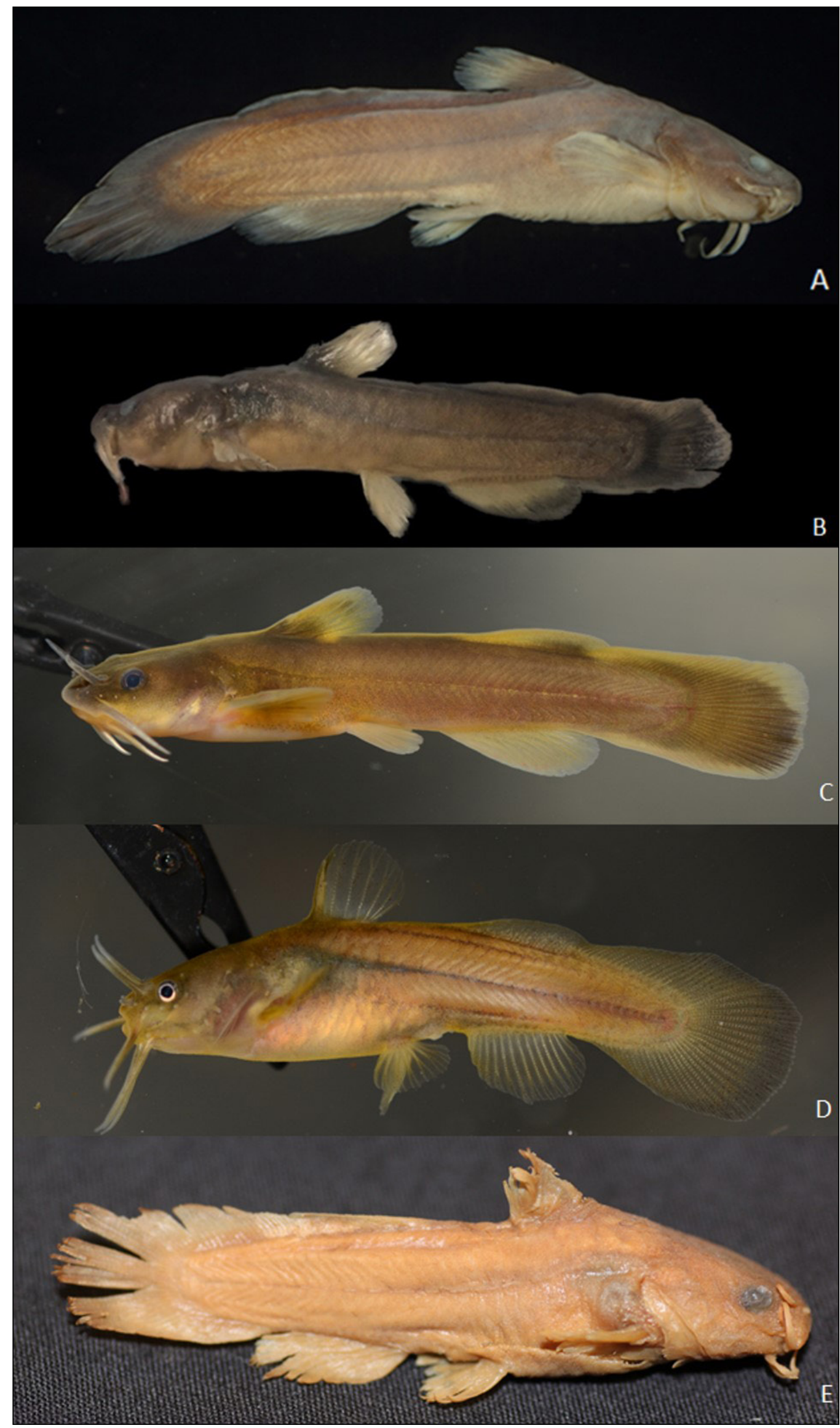

FIGURE 2. The Freckled Madtom (Noturus nocturnus) collected on 28 September 2005 by ORSANCO (A), the Freckled Madtom collected on 5 September 2019 by MBI (B), a Stonecat Madtom (Noturus flavus) (C), a Tadpole Madtom (Noturus gyrinus) (D), and the Tadpole $\times$ Brindled Madtom (N. gyrinus $\times$ N. miurus) described by Trautman (E) 
Table

Comparison of 4 Noturus species in the state of Ohio (including the Freckled Madtom), the Freckled Madtom specimens collected by ORSANCO and MBI, and the hybrid Noturus specimen collected by Edward Wickliff. The left 4 columns are the general identifying characteristics as noted in The Fishes of Tennessee* (Etnier and Starnes 1993) for the 4 species of interest in this paper and the right 3 columns are the Freckled Madtom specimens collected by ORSANCO and MBI in addition to the hybrid Noturus collected by Edward Wickliff and described by Milton Trautman.

\begin{tabular}{|c|c|c|c|c|c|c|c|}
\hline $\begin{array}{l}\text { Meristic } \\
\text { characteristics }\end{array}$ & $\begin{array}{l}\text { Tadpole } \\
\text { Madtom }^{3} \\
\text { (Noturus } \\
\text { gyrinus) }\end{array}$ & $\begin{array}{l}\text { Stonecat } \\
\text { Madtom }^{3} \\
\text { (Noturus }^{\text {Navus) }}\end{array}$ & $\begin{array}{l}\text { Brindled } \\
\text { Madtom }^{3} \\
\text { (Noturus }^{\text {miurus) }}\end{array}$ & $\begin{array}{l}\text { Freckled } \\
\text { Madtom }^{3} \\
\text { (Noturus } \\
\text { nocturnus) }\end{array}$ & $\begin{array}{l}\text { Freckled } \\
\text { Madtom }^{4} \\
\text { (Noturus } \\
\text { nocturnus) } \\
\text { ORSANCO }\end{array}$ & $\begin{array}{l}\text { Freckled } \\
\text { Madtom }^{5} \\
\text { (Noturus } \\
\text { nocturnus) } \\
\text { MBI }\end{array}$ & $\begin{array}{l}\text { Hybrid } \\
\text { Madtom }^{2,5} \\
\text { (N. gyrinus } \times \\
\text { N. miurus) } \\
\text { E. Wickliff }\end{array}$ \\
\hline Anal fin rays & $13-18$ & $15-18$ & $13-17$ & $15-19$ & 16 & 19 & 15 \\
\hline Soft pectoral fin rays ${ }^{1}$ & $5-10$ & $10(8-10)$ & $8(7-9)$ & $9(8-10)$ & $9 / 9$ & $10 / 9$ & $7 / 7$ \\
\hline Pelvic fin rays ${ }^{1}$ & $5-10$ & $9(8-10)$ & $9(8-10)$ & $9(8-10)$ & $9 / 9$ & $9 / 9$ & $9 / 9$ \\
\hline Caudal fin rays & $50-66$ & $55-67$ & $55-64$ & $55-64$ & 55 & 58 & 58 \\
\hline $\begin{array}{l}\text { Light saddle post } \\
\text { dorsal fin }\end{array}$ & - & $\mathrm{X}$ & - & - & - & - & NA \\
\hline $\begin{array}{l}\text { Backward extensions } \\
\text { of premaxillary teeth }\end{array}$ & - & $\mathrm{X}$ & - & - & - & - & - \\
\hline $\begin{array}{l}\text { Dark marginal bands } \\
\text { on median fins }\end{array}$ & - & - & - & $\mathrm{X}$ & $\mathrm{X}$ & $\mathrm{X}$ & NA \\
\hline $\begin{array}{l}\text { Melanophores on } \\
\text { head and behind } \\
\text { pelvic fins }\end{array}$ & - & - & - & $\mathrm{X}$ & $\mathrm{X}$ & $\mathrm{X}$ & NA \\
\hline $\begin{array}{l}\text { Upper and lower } \\
\text { jaws equal }\end{array}$ & $\mathrm{X}$ & - & - & - & - & - & NA \\
\hline $\begin{array}{l}\text { Number of barbs on } \\
\text { pectoral spines }\end{array}$ & 0 & 0 & $5-7$ & 0 & $0 / 0$ & $0 / 0$ & $3 / 3$ \\
\hline
\end{tabular}

${ }^{1}$ Paired fins are denoted as left/right on collected specimens.

${ }^{2}$ Described by Trautman in Copeia Vol. 1948(3); coloration is degraded due to high formalin concentration at time of preservation.

${ }^{3}$ Meristic traits and identifying characteristics are described from The Fishes of Tennessee.

${ }^{4}$ Identification of characteristics and fin ray counts provided by Doug Fischer of the PA Division of Environmental Services.

${ }^{5}$ Identification of characteristics and fin ray counts provided by Marc Kibbey of the OSUMBD.

* The Fishes of Tennessee was used in this table to compare the morphological differences of the species and hybrid analyzed because all species occur in Tennessee, Tennessee is close in proximity to Ohio, and the book provides excellent descriptions of the identifying characteristics for each species including color patterns, fin ray counts, and number of pectoral spine barbs. 


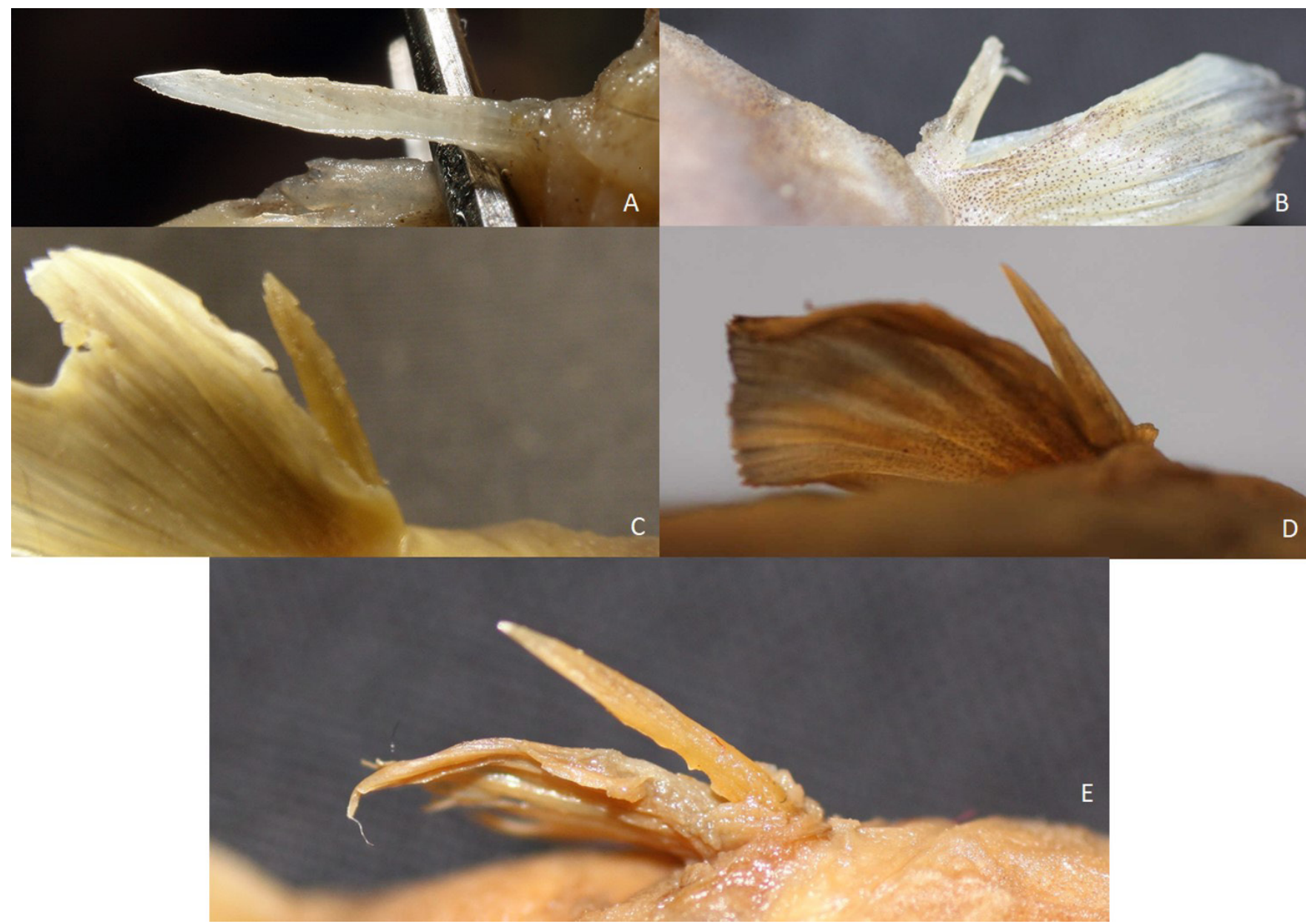

FIGURE 3. Pectoral spines from the Freckled Madtom (Noturus nocturnus) collected on 28 September 2005 by ORSANCO (A), the Freckled Madtom collected on 5 September 2019 by MBI (B), a Stonecat Madtom (Noturus flavus) (C), a Tadpole Madtom (Noturus gyrinus) (D), and the Tadpole $\times$ Brindled Madtom (N. gyrinus $\times$ N. miurus) described by Trautman (E). Post preservation, both of the pectoral spines on the MBI Freckled Madtom (B) were damaged. The image is of the longest pectoral spine available on the specimen.

Ohio. The nearest historical locality to the Scioto River specimen is the Little Sandy River in Kentucky, which converges with the Ohio River 32.2 river $\mathrm{km}$ (20.0 river $\mathrm{mi}$ ) upstream of the Scioto River. Specimens from these drainages have not been obtained since the collections by Turner in 1959 from Levisa Fork within the Big Sandy River basin and Taylor in 1969 from Laurel Creek within the Little Sandy River basin (Clay 1975). Furthermore, the Needle Dam at Louisa, Kentucky, on the Big Sandy River, makes downstream dispersal to the Ohio River more difficult for this diminutive species (Clay 1975). A recent collection of Freckled Madtom in the Ohio River by Brant Fisher (personal communication on 30 November 2020 from Brant Fisher to the authors; unreferenced) of the Indiana Department of Natural Resources (IDNR) occurred in 2018 at the border of Indiana and Kentucky (Fig. 1). That particular collection occurred roughly 450 river $\mathrm{km}$ (280 river $\mathrm{mi}$ ) downstream of the Scioto River confluence with the Ohio River and coincides with known populations in the lower Wabash River.

The Oklahoma Conservation Commission (2015) classifies Freckled Madtom as an intolerant, sensitive species and an indicator of excellent water quality. Jester et al. (1992) observed that the species is moderately intolerant of poor water quality and habitat degradation. Prior to the 1972 mandated Clean Water Act (CWA), controls of water pollution from point sources along the Scioto River ranged from limited to nonexistent, the same as in other Ohio River tributaries that were heavily polluted. Post-CWA improvements in the fish assemblages within the middle reaches of the Scioto River, documented by Yoder et al. (2019), show significantly increased ranges for nearly 70 fish species-most of which are moderately to highly intolerant of pollution. Ohio EPA (2019) 
found similar degrees of improvement in the lower mainstem. This further indicates that the Scioto River, from the mouth at the Ohio River to the Greenlawn Dam upstream at river $\mathrm{km} 208.4$ (river mi 129.5) in Columbus, is more than adequate to support intolerant species such as Freckled Madtom. The newfound presence of a species with known intolerance to poor water quality and habitat modifications (in a state which has experienced decades of unchecked pollution, habitat alteration of small to moderate streams, and siltation of natural substrates) also raises the possibility that this species was extirpated before the extensive fish collections in the late 1980 to 2015 period alluded to by Rice and Zimmerman (2019).

The Ohio River can serve as a route for fish species to move from one tributary drainage to another. However, the Ohio River generally does not offer suitable Noturus spp. habitat on a continuous basis due to the impoundments created by the series of locks and dams that have reduced riffle habitats in extensive reaches of the mainstem. The presence of these small catfishes also indicates water quality suitable for the occurrence of intolerant and sensitive fish species in the Ohio River mainstem, which has also recovered from decades of serious water pollution (Thomas et al. 2019).

\section{Conclusions}

The apparent rarity of Freckled Madtom in its eastern range, and the lack of prior records in Ohio, could have contributed to this species being overlooked via misidentification; similar to what initially happened with the 2 Ohio specimens that were the subject of this study. The recent appearance of the Freckled Madtom in the upper Ohio River and lower Scioto River could also be the result of improved water quality. At the very least, the documentation and awareness of the taxonomic issues revealed by these new Ohio records makes the wider occurrence of Freckled Madtom a possibility that should enhance the discovery of future locations.

\section{ACKNOWLEDGEMENTS}

The authors would like to thank Marc Kibbey, Associate Curator of Fishes, at The Ohio State University Museum of Biological Diversity (OSUMBD) and Brian Zimmerman, Research Associate, at The Ohio State University Stream \& River Ecology (STRIVE) Lab for identification of the 2 Freckled Madtom specimens found in Ohio. Brant Fisher of the Indiana Department of Natural Resources provided Freckled Madtom localities in the state of Indiana. Marc Kibbey, Edward Rankin, and Brian Zimmerman reviewed early versions of the manuscript. Arc of Appalachia is also acknowledged for partially funding the Scioto River biological assessment in 2019, as is MBI for providing the balance of the support. Jay $\mathrm{R}$. Stauffer, Jr. made the specimen available from the Penn State University (PSU) Fish Museum. Nathan Weyandt (PSU staff) and Doug Fischer (PADivision of Environmental Services) are acknowledged for their review of the PSU specimen. Zach Alley and Justin England assisted with the collection of the Scioto River specimen, Rob Criswell provided the PSU Freckled Madtom specimen photograph, Brian Zimmerman provided the Stonecat Madtom and Tadpole Madtom photographs, and Marc Kibbey provided the Tadpole $\times$ Brindled Madtom specimen and Noturus spp. pectoral spine photographs. 


\section{LITERATURE CITED}

Burr BM. 1980. A distributional checklist of the fishes of Kentucky. Brimleyana. 3:53-84.

https://www.biodiversitylibrary.org/page/53741611 http://www.nativefishlab.net/library/textpdf/14049.pdf

Burr BM, Mayden RL. 1982. Life history of the Freckled Madtom, Noturus nocturnus, in Mill Creek, Illinois (Pisces: Ictaluridae). Occasional Pap Mus Nat Hist. 98:1-15. The University of Kansas.

https://www.biodiversitylibrary.org/page/4467983

Burr BM, Warren MLJr, Bennett MG. 2020. Ictaluridae: North American catfishes. In: Warren ML Jr, Burr BM, editors. Freshwater fishes of North America, volume 2: Characidae to Poeciliidae. Baltimore (MD): Johns Hopkins University Press. Chapter 15. p. 23-148. ISBN 13: 9781421435138.

Clay WM. 1975. The fishes of Kentucky. Frankfort (KY): Kentucky Department of Fish and Wildlife Resources. p. 218-220.

Eberle ME. 2014. Freckled Madtom Noturus nocturnus Jordan and Gilbert 1986. In: Distler DA, Tomelleri JR. Kansas Fishes. Lawrence (KS): University Press of Kansas. p. 301302. ISBN13: 9780700619610.

Etnier DA, Starnes WC. 1993. The fishes of Tennessee. Knoxville (TN): The University of Tennessee Press. p. 325-326. ISBN 13: 9780870497117.

Jester DB, Echelle AA, Matthews WJ, Pigg J, Scott CM, Collins KD. 1992. The fishes of Oklahoma, their gross habitats, and their tolerance of degradation in water quality and habitat. Proc Okla Acad Sci. 72:7-19.

https://ojs.library.okstate.edu/osu/index.php/OAS/article/view/5494

Mettee MF, O'Neil PE, Pierson JM. 1996. Fishes of Alabama and the Mobile Basin. Birmingham (AL): Oxmoor House. p. 410-411. ISBN 13: 9780848714857.

Ohio EPA. 2019. Biological and water quality study of the lower Scioto River and selected tributaries, 2011: Pickaway, Ross, Pike and Scioto Counties, Ohio. Columbus $(\mathrm{OH})$ : State of Ohio Environmental Protection Agency, Division of Surface Water. 56 p. Ohio EPA Technical Report AMS/2011-LSCIO-2.

https://www.epa.state.oh.us/dsw/document_index/psdindx

Ohio EPA. 1989. [Addendum to] Biological criteria for the protection of aquatic life, volume II: user's manual for biological field assessment of Ohio surface waters. Columbus $(\mathrm{OH})$ : Ohio Environmental Protection Agency, Division of Water Quality Planning and Assessment, Surface Water Section. 60 p. Report dated 30 September 1989. Addendum to earlier report, of same name, dated 30 October 1987 (updated 1 January 1988).

https://www.epa.state.oh.us/dsw/bioassess/BioCriteriaProtAqLife

Oklahoma Conservation Commission. 2015. Assessment of fish. Oklahoma City (OK): Oklahoma Conservation Commission, Water Quality Division. [updated 2015 Mar 5; accessed 2020 Nov 11]: [about 1 screen] .

https://conservation.ok.gov/qa-monitoring-programassessment-of-stream-aquatic-communities/
Page LM, Burr BM. 2011. Peterson field guide to freshwater fishes of North America north of Mexico. 2nd ed. Boston (MA): Houghton Mifflin Harcourt. p. 355-356. ISBN 13: 9780547242064.

Pflieger WL. 1997. The fishes of Missouri. Rev. ed. Jefferson City (MO): Missouri Department of Conservation. 372 p. ISBN 13: 9781887247115.

Rice DL, Zimmerman B. 2019. A naturalist's guide to the fishes of Ohio. Columbus (OH): Ohio Biological Survey. p. 361. Special publication of the Ohio Biological Survey, volumeXVIIII [sic]-new series. ISBN 13: 9780867271676.

Robison HW, Buchanan TM. 2020. Fishes of Arkansas. 2nd ed. Fayetteville (AR): The University of Arkansas Press. p. 460-462. ISBN 13: 9781682261033.

Ross ST. 2001. Inland fishes of Mississippi. Jackson (MS): University Press of Mississippi. 624 p. ISBN 13: 9781578062461.

Smith PW. 1979. The fishes of Illinois. Urbana (IL): University of Illinois Press. p. 191-192. ISBN 13: 9780252006821.

Thomas JA, Schulte JG, Tennant PA, Argo DR. 2019. Recovery of a great river fishery: the story of the Ohio River. In: Krueger CC, Taylor WW, Youn SJ, editors. From catastrophe to recovery: stories of fishery management success. Bethesda (MD): American Fisheries Society. p. 211-231. ISBN 13: 9781934874554. https://doi.org/10.47886/9781934874554.ch9

Thomas JA, Emery EB, McCormick FH. 2004. Detection of temporal trends in Ohio River fish assemblages based on lockchamber surveys (1957-2001). In: Rinne JN, Hughes RM, and Calamusso B, editors. Historical changes in large river fish assemblages of the Americas. Bethesda (MD): American Fisheries Society. AFS Symposium 45, Chapter 22, c2005. ISBN 13: 9781888569728.

https://www.researchgate.net/publication/228656974_ Detection_of_temporal_trends_in_Ohio_River_fish_ assemblages_based_on_lockchamber_surveys_1957-2001 . https://doi.org/10.47886/9781888569728.ch22

Trautman MB. 1948. A natural hybrid catfish, Schilbeodesmiurus $\times$ Schilbeodes mollis. Copeia. 1948(3):166-174 https://doi.org/10.2307/1438451

Turner WR. 1959. Pre-impoundment surveys of six Kentucky streams. Frankfort (KY): [Kentucky] Department of Fish and Wildlife Resources, Division of Fisheries. 45 p. Fisheries Bulletin No.: 24. Federal aid to fisheries, Project F-10-R. Final report.

https://fw.ky.gov/Fish/Documents/FishBulletin024.pdf

Yoder CO, Rankin ET, Gordon VL, Hersha LE, Boucher CE. 2019. Degradation and recovery of Scioto River (Ohio, USA) fish assemblages from presettlement to present-day conditions. In: Krueger CC, Taylor WW, Youn SJ, editors. From catastrophe to recovery: stories of fishery management success. Bethesda (MD): American Fisheries Society. p. 233-265. ISBN 13: 9781934874554. https://doi.org/10.47886/9781934874554.ch10 